\title{
Canada has 1838 drinking-water advisories
}

A t least 1838 drinking-water advisories were in place at the start of 2015, in communities across Canada, including 129 First Nations, reports the Council of Canadians.

The national nonprofit, social-action organization compiled the snapshot of water quality across Canada as of January, in its Mar. 12 report On Notice for a Drinking Water Crisis in Canada. It highlights the "tenuous" access people in many municipalities and First Nations communities have to safe drinking water. The report also advances the Council of Canadians' campaign to consider the impact of pipelines, dams and other development projects on water sources.

The report calls on the federal government to develop a national water policy that establishes enforceable drinking-water standards, addresses water pollution and invests in water and waste water infrastructure, particularly in First Nations communities, among other recommendations. "These numbers and this information really show that there's a long-standing problem that governments need to address, and we really see that with First Nations communities," says Emma Lui, the council's water campaigner and author of the report. "It's something that can't go on any longer."

The total number of water-quality advisories is likely underestimated in the report, Lui says, because not all health authorities report the advisories they issue.

The highest number of advisories 544 - are in place in British Columbia, followed by Saskatchewan with 294, and Newfoundland and Labrador with 233.

There are three levels of water-quality advisories: boil water before drinking it; do not consume water at all; and precautionary advisories. Multiple advisories may be issued for one community if there is a problem with water quality in more than one location. They may be issued for municipal water systems, towns, specific apartment buildings, schools, parks, campgrounds, stores and restaurants, the report states.

Although the locations of the waterquality advisories have shifted over the last seven years, the total number has changed little since 2008, when $C M A J$ 's investigation into water quality unearthed 1766 boil-water advisories across the country and highlighted Aboriginal and municipal leaders' concerns about the state of this social determinant of health. (CMAJ's 2008 figures did not include First Nations communities.)

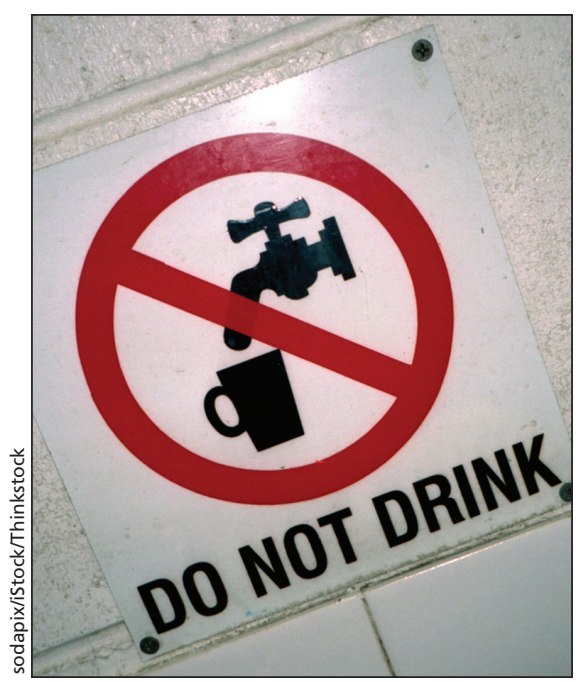

Canada has a long-standing problem with drinking water quality, particularly in First Nations communities, states the Council of Canadians.

Canada has guidelines for drinkingwater quality, but lacks any binding federal legislation to impose national standards. The council's report highlights regulatory gaps in several provinces and territories, and praises the Northwest Territories for being the only jurisdiction to declare access to water a human right.

In general, advisories are issued for reasons that include unacceptable microbiological quality, inadequate disinfection, substantial deterioration in source water, water quality that fails to meet the Canadian Drinking Water Guidelines, unacceptable turbidity (cloudiness) or particle count, a high total coliform count or the presence of E. coli bacteria, as well as equipment malfunction during water treatment or distribution. In at least one First Nations community - Kitigan Zibi in Quebec - unacceptable levels of uranium are responsible for a do-not-consume order that has been in place since 1999 .
Although the report argues that resource and development projects including uranium mines, pipelines and fracking threaten Canada's supply of safe drinking water, it is impossible to link the water-quality advisories directly to particular projects, because few provinces and territories specify the reasons why, for instance, source or ground water is contaminated.

Water quality has been a persistent problem in one of every six First Nations communities, says Cindy Blackstock of the First Nations Child \& Family Caring Society of Canada. As of Jan. 31, Health Canada reported 136 drinking-water advisories in 93 First Nations communities across Canada, excluding BC.

BC's First Nations Health Authority, which is responsible for water-quality advisories in that province, reported 32 drinking-water advisories in effect in 28 First Nations communities as of Feb. 28.

Such advisories are intended to be transitory. But among some First Nations communities, these warnings have been in place for years. Of the 100 or so water advisories reported annually among First Nations communities, more than half will have been in place for 5 to 15 years, the report points out.

The Slate Falls First Nation north of Sioux Lookout, Ont. has had a boil-water advisory in effect since 2004, affecting upwards of 200 people. More than 1000 people living on the Eabametoong First Nation in Fort Hope, Ont., have not been able to drink or cook with water without boiling it since 2001 .

In Manitoba, the Shoal Lake 40 First Nation has had a boil-water advisory in effect for 17 years, as some of its members pointed out when parts of Winnipeg came under a precautionary boil-water advisory briefly in January. — Laura Eggertson, Ottawa, Ont.

CMAJ 2015. DOI:10.1503/cmaj.109-5018

\section{More News online}

To read more CMAJ news articles, visit cmaj.ca/site/home/news.xhtml 